\title{
Enrichment and Separation of Fe(III), Mn(II), Ni(II), and Zn(II) as Their Congo Red Chelates on Multiwalled Carbon Nanotube (MWCNT) Disk in Food and Water Samples
}

\author{
Ilknur Durukan ${ }^{\mathrm{a}}$, Mustafa Soylak ${ }^{\mathrm{b},{ }^{*}, \text { and Mehmet Dogan }}{ }^{\mathrm{a}}$ \\ ${ }^{a}$ Hacettepe University, Faculty of Science, Department of Chemistry, Beytepe, 06800 Ankara, Turkey \\ ${ }^{b}$ Erciyes University, Faculty of Sciences, Department of Chemistry, 38039 Kayseri, Turkey
}

\section{INTRODUCTION}

Heavy metals are major environmental pollutants and one of the most serious environmental problems. The treatment of metals at trace levels is of special concern due to their recalcitrance and persistence in the environment $(1,2)$. Because of their long-term effects on health, the detection of elements at trace levels in environmental samples is of special concern (3).

Flame atomic absorption spectrometry (FAAS) is a widely used instrumental technique for trace metal determination. However, levels of the analyte elements that are lower than the limit of detection of FAAS and interferences from coexisting ions are the limitations of this technique $(4,5)$. To solve these limitations (6), solid phase extraction (SPE) is the enrichment-separation method that effectively enhances the sensitivity and selectivity of FAAS in saline samples. The advantages of using SPE include its ability for quantitative recoveries, offering high enrichment factors, easy application, and use of green technique (7).

Carbon nanotubes $(8,9)$ have attracted much attention as solid phase extractants. They offer easy preconcentration and separation of metal ions such as lead $(10,11)$, cadmium (12), chromium $(13,14)$, copper (15), and nickel (16) from water and food samples. Congo Red

*Corresponding author.

E-mail: soylak@erciyes.edu.tr

Fax: +903524374933

\section{ABSTRACT}

In this study, a novel method of using multiwalled carbon nanotube disk-solid phase extraction (MWCNT disk-SPE) of iron, manganese, nickel, and zinc in food and water samples is described. Congo Red (CR) was used as the chelating agent. The analytical parameters of the MWCNT diskSPE system, including $\mathrm{pH}$, amount of CR, sample volume, type of eluent, and sample flow rates, were investigated. Detection limits of $4.2,1.2,2.1$, and $1.8 \mathrm{ng} / \mathrm{mL}$ for iron, manganese, nickel, and zinc, respectively, were obtained and a preconcentration factor of 25 was achieved. The SPE technique was applied to the determination of analyte elements in certified reference materials, water and food samples with satisfactory results.

(CR) is an important reagent for metal complexation and can be used in SPE studies (Figure1). According to our literature survey, no work has been published using the combination of Congo Red and a multiwalled carbon nanotube disk.
In the present work, a solid phase extraction procedure for the separation and enrichment of trace amounts of iron(III), manganese(II), nickel(II), and zinc(II) as their Congo Red chelates in environmental samples on a MWCNT disk has been established. The analytical parameters for the quantitative recoveries of the analytes were investigated and optimized.

\section{EXPERIMENTAL}

\section{Instrumentation}

A Model AAnalyst ${ }^{\mathrm{TM}} 800$ atomic absorption spectrometer (PerkinElmer, Inc., Shelton, CT, USA), equipped with an air-acetylene burner (17/2.1 L/min), was used. PerkinElmer hollow cathode lamps were used as light sources, using a $0.2 \mathrm{~nm}$ slit width. Deuterium lamp background correction was employed. The operating parameters for the instrument were set as recommended by the manufacturer and are listed in Table I. A Model Ethos Plus microwave labstation with computer-controlled easywave software (Milestone, CT, USA) was used to digest the solid samples. The $\mathrm{pH}$ was measured using an Accument $15 \mathrm{pH}$ meter (Fisher Scientific, USA).

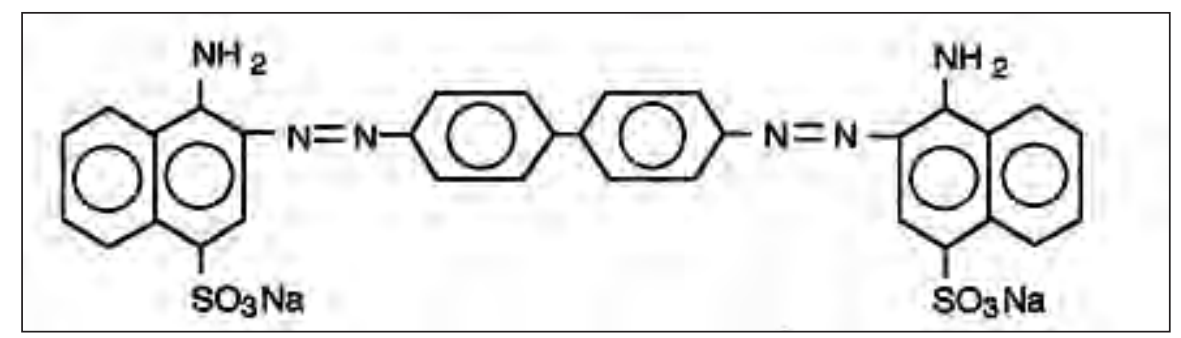

Fig. 1. Congo Red. 


\section{Reagents and Solutions}

High purity chemicals were used in this study (E. Merck, Darmstadt, Germany) without additional purification. All solutions were prepared with reverse osmosis deionized water (Barnstead, Dobuque, IA, USA, $18.2 \mathrm{M} \Omega \mathrm{cm}$ ). For preparation of the standard stock solutions with an analyte concentration of $1000 \mathrm{mg} / \mathrm{L}$, nitrate salts of the investigated analyte ions were used in $1 \mathrm{~L}$ calibrated flasks with $1 \%$ of $\mathrm{HNO}_{3}$. The sample solutions were obtained by dilution of the stock standard solutions daily. The chelating reagent, $0.2 \%(\mathrm{w} / \mathrm{v}) \mathrm{CR}$, was prepared daily by dissolving the appropriate amounts of CR (B.D.H., Poole, England) in deionized water. For $\mathrm{pH}$ adjustment, a buffer solution was prepared using $100 \mathrm{~mL}$ of $0.025 \mathrm{M}$ $\mathrm{Na}_{2} \mathrm{~B}_{4} \mathrm{O}_{7} \cdot 10 \mathrm{H}_{2} \mathrm{O}$ (borax) (Fluka) and $9.2 \mathrm{~mL}$ of $0.1 \mathrm{M} \mathrm{HCl}$ (Merck). In the elution step, $\mathrm{HNO}_{3}$ (Merck) and acetone (Merck) were used.

Certified reference material (CRM) NCS ZC 73012 Cabbage from the China National Analysis Center for Iron and Steel (Beijing, P.R. China) and SPS SW1 Surface water from SpectraPure ${ }^{\circledR}$ Standards (Holger Teknologi AS, Norway) were used for method validation. Multi-walled carbon nanotubes (MWNT) (No. 636614) were purchased from Aldrich, Milwaukee, WI, USA.

\section{Preparation of MWCNT Disk}

The suspension, containing $40 \mathrm{mg}$ of MWCNTs in $50 \mathrm{~mL}$ of $5 \%$ (w/v) sodium dodecyl sulfate, was

TABLE I

Instrument Settings

\begin{tabular}{cccc}
\hline $\begin{array}{c}\text { Ele- } \\
\text { ments }\end{array}$ & $\begin{array}{c}\text { Wave- } \\
\text { length } \\
\text { (nm) }\end{array}$ & $\begin{array}{c}\text { Slit } \\
\text { Width } \\
\text { (nm) }\end{array}$ & $\begin{array}{c}\text { Lamp } \\
\text { Current } \\
\text { (mA) }\end{array}$ \\
\hline $\mathrm{Fe}$ & 248.3 & 0.2 & 35 \\
$\mathrm{Mn}$ & 279.5 & 0.2 & 20 \\
$\mathrm{Ni}$ & 232.0 & 0.2 & 25 \\
$\mathrm{Zn}$ & 213.9 & 0.7 & 15 \\
\hline
\end{tabular}

filtered through a 47-mm diameter cellulose acetate membrane filter paper by using a vacuum pump to prepare a multiwalled carbon nanotube disk (Figure 2). Thus, the MWCNT adsorbents were distributed uniformly on the filter. The disk was washed with water and then allowed to dry at room temperature.

\section{Procedure for FAAS Analysis}

Treatment of the proposed method was performed for sample solutions prior to its application to real samples. A $25-\mathrm{mL}$ amount of the sample solution containing $20 \mu \mathrm{g}$ Fe(III) and Ni(II), $10 \mu \mathrm{g}$ $\mathrm{Mn}$ (II) and $\mathrm{Zn}$ (II), $3 \mathrm{~mL}$ of $\mathrm{pH} 9$ buffer solution, and $1 \mathrm{~mL}$ of CR chelating agent $(0.2 \% \mathrm{w} / \mathrm{v})$ was passed through the disk at a pump flow rate of $1.5 \mathrm{~mL} / \mathrm{min}$. After passage of the solution, the nanotube disk was washed with a related buffer solution. Then, the retained metal ions were desorbed from the disk with the aid of the $10 \mathrm{~mL}$ solution of $1 \mathrm{M} \mathrm{HNO}_{3}$ at a $3.0 \mathrm{~mL} / \mathrm{min}$ flow rate. The glass filtration apparatus was washed with $2 \mathrm{M} \mathrm{HNO}_{3}$ in acetone and then with deionized water before passing the next solution. The final solution was heated to evaporate the acetone, and the volume adjusted to $10 \mathrm{~mL}$ with $1 \mathrm{M}$ $\mathrm{HNO}_{3}$. The metal levels were determined by FAAS.

\section{Samples and Sample Pretreat- ment}

White bread, lettuce, zucchini, tomato, almonds and hazelnuts were purchased at local Ankara

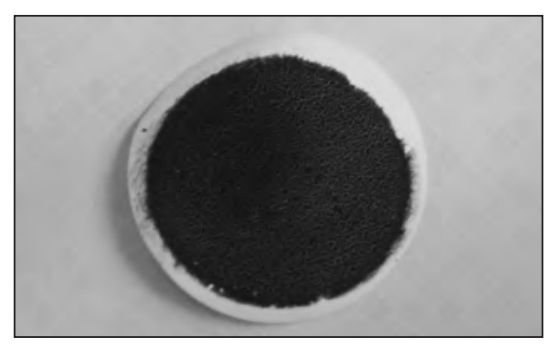

Fig. 2. Photograph of the MWCNT disk.

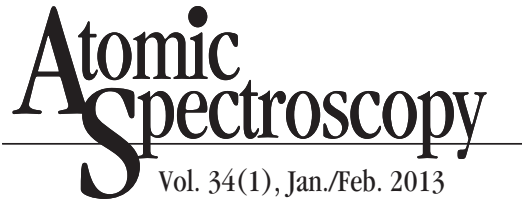

markets. Samples of lettuce, zucchini, tomato, almond and hazelnuts were cleaned with tap and deionized water. The NCS ZC 73012 Cabbage CRM, vegetable and bread samples were dried at $105^{\circ} \mathrm{C}$ for 24 hours, and then all samples (including the almonds and hazelnuts) were ground to a particle size of approximately $0.3 \mathrm{~mm}$. Then, $200 \mathrm{mg}$ of each sample, including the cabbabe CRM, was digested in the Ethos Plus microwave oven with $3 \mathrm{~mL}$ of $\mathrm{HNO}_{3}$ and $2 \mathrm{~mL}$ of $\mathrm{H}_{2} \mathrm{O}_{2}$. The steps for the digestion procedure were obtained from the literature (17). The digested solutions were left standing to cool, and each was then transferred into $250-\mathrm{mL}$ volumetric flasks and diluted with deionized water. The digested cabbage CRM was diluted with $50 \mathrm{~mL}$ of distilled water. Then the FAAS procedure given above was applied to all of these solutions.

\section{RESULTS AND DISCUSSION}

Influences of pH on the Recovery of the Analytes

Since $\mathrm{pH}$ plays an important role in the quantitative extraction of metal ions in solid phase extraction (18-24), the influence of $\mathrm{pH}$ on the recovery of the analyte elements was examined ranging from 3.011.0. As shown in Figure 3, best quantitative recovery values were obtained at $\mathrm{pH} 9$, which was chosen for subsequent experiments.

\section{Influence of Congo Red Concentration}

The concentration of ligand in the solid phase extraction studies is also a key factor for the quantitative recoveries of analyte elements (2530). The influence of CR concentration on the recovery of the analyte elements was tested in the range of $0.005-0.4 \%(w / v)$. The SPE efficiency increased as the level of CR increased from 0.005 to $0.2 \%(\mathrm{w} / \mathrm{v})$ and then almost remained constant at the concentration of $0.4 \%(\mathrm{w} / \mathrm{v})$. 
TABLE II

Effects of Eluent Type on the Recovery Values

\begin{tabular}{lcccc}
\hline & \multicolumn{4}{c}{ Recovery (\%) } \\
\hline Eluent Type & Fe(III) & Mn(II) & Ni(II) & $\mathrm{Zn}(\mathrm{II})$ \\
\hline $1 \mathrm{M} \mathrm{HNO}_{3}$ & 88 & 89 & 97 & 89 \\
$2 \mathrm{M} \mathrm{HNO}_{3}$ & 92 & 91 & 96 & 89 \\
$3 \mathrm{M} \mathrm{HNO}_{3}$ & 94 & 94 & 95 & 90 \\
$3 \mathrm{M} \mathrm{HCl}^{\mathrm{M} \mathrm{HNO}}$ in acetone & 99 & 93 & 94 & 88 \\
$1 \mathrm{M} \mathrm{HCl}^{\text {in acetone }}$ & 97 & 97 & 101 & 98 \\
\hline
\end{tabular}

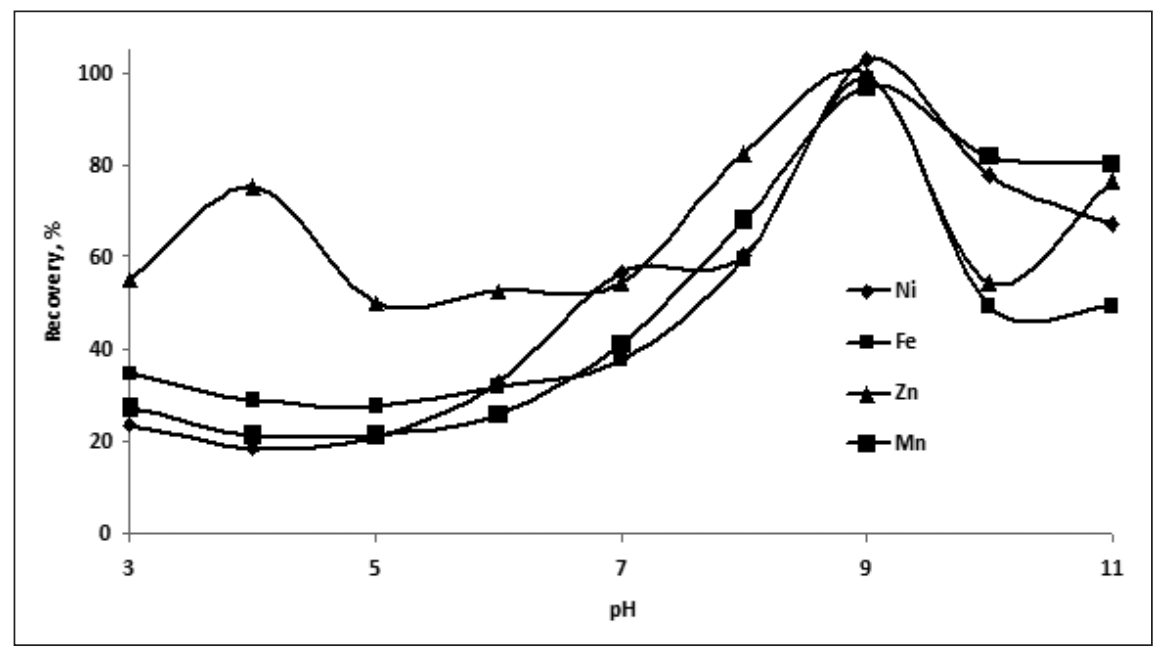

Fig. 3. Relationship between $\mathrm{pH}$ and analyte recovery $(n=3)$.

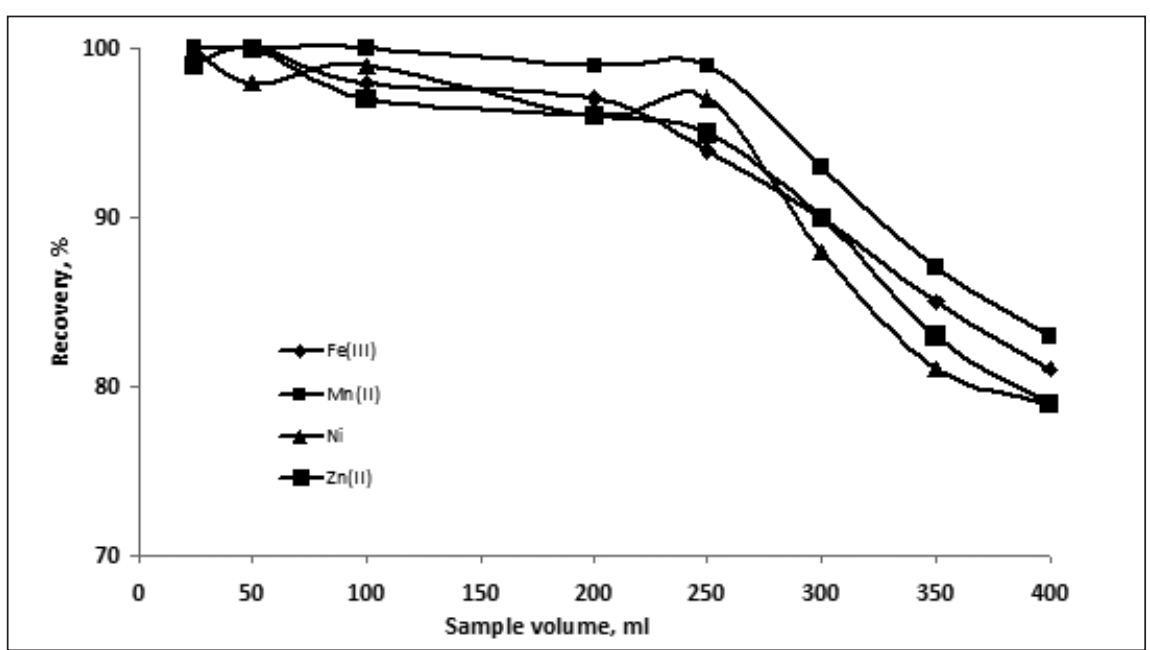

Fig. 4. The effects of sample volume on the recovery values $(n=3)$.
A CR concentration of $0.1 \%(\mathrm{w} / \mathrm{v})$ was selected for further study.

\section{Elution}

The different concentrations of the solvents listed in Table II were tested, and high quantitative recoveries were obtained. However, the highest recovery values for all of the analyte ions were obtained with $1.0 \mathrm{M} \mathrm{HNO}_{3}$ in acetone. So, $1.0 \mathrm{M}$ $\mathrm{HNO}_{3}$ in acetone was selected as the eluent for MWCNT disk-SPE. The optimum eluent volume was also tested, and quantitative recovery values were obtained both at 5 and $10 \mathrm{~mL}$ of eluent volume.

\section{Sample and Eluent Flow Rates}

The effect of sample flow rate on the recovery of the elements was studied with sample solutions ranging from $0.5-3.0 \mathrm{~mL} / \mathrm{min}$. The recovery values decreased slightly with an increase in sample flow rate above $1.5 \mathrm{~mL} / \mathrm{min}$ because of incomplete retention of the metal chelates on the MWCNT disk. For further studies, a sample flow rate of $1.5 \mathrm{~mL} / \mathrm{min}$ was selected.

The effect of elution rates from 0.5 to $4.0 \mathrm{~mL} / \mathrm{min}$ was studied. The recoveries decreased with increasing the eluent flow rate above $3.0 \mathrm{~mL} / \mathrm{min}$. Thus, all further work was carried out using a $3.0 \mathrm{~mL} / \mathrm{min}$ flow rate for the eluent solutions.

\section{Effect of Sample Volume}

The influence of sample volume on the recovery of $\mathrm{Fe}(\mathrm{III}), \mathrm{Mn}$ (II), $\mathrm{Ni}(\mathrm{II})$, and $\mathrm{Zn}$ (II) using MWCNT disk-SPE was investigated with sample solutions ranging from 25-400 mL. Figure 4 shows that the recoveries were found to be stable until $250 \mathrm{~mL}$. The preconcentration factor was calculated by the ratio of the highest sample volume (250 $\mathrm{mL})$ and the final volume $(10 \mathrm{~mL})$. The preconcentration factor was 25. 


\section{Interferences}

"Matrix Effect" is a well-known problem for the flame atomic absorption spectrometric determination of metal ions in saline samples (31-39). The interference of cations and anions on the present enrichment-separation system were examined under optimized conditions. The results are summarized in Table III. Since the recovery values for the analyte elements are generally quantitative in the presence of the investigated foreign ions, it was found that the proposed extraction method can be applied to saline samples.

\section{Performance of Proposed Method}

The detection limits, defined as the concentration equivalent to three times the standard deviation $(\mathrm{N}=20$ ) of the reagent blank, are listed in Table IV. The precision of the present enrichment method, calculated as the relative standard deviation of the measurements carried out with the sample solutions $(\mathrm{N}=9)$, was below $2.3 \%$.
Tests of addition/recovery in the experiments for analyte ions were performed using seawater, mineral water, and tap water samples. The results listed in Table $\mathrm{V}$ show that good agreement was obtained between the added and measured analyte values. The recoveries were quantitative and showed that the method can be applied for the separation/enrichment of analytes in real samples.

The present MWCNT disk-SPE procedure was applied to SPS SW1 Surface Water and NCS ZC 73012 Cabbage certified reference material. The results given in Table VI show that the certified values and the recoveries are in the acceptable range.

\section{Applications}

The applicability and reliability of the proposed method for the determination of iron, manganese, nickel, and zinc in food samples was investigated. The results listed in Table VII show that analyte elements at $\mu \mathrm{g} / \mathrm{g}$ levels can easily be determined by FAAS after using the

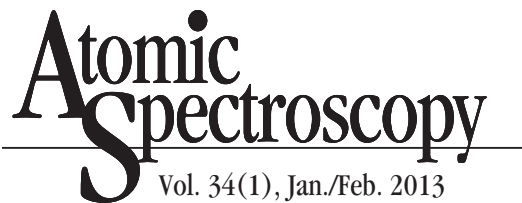

proposed solid phase extraction procedure.

\section{CONCLUSION}

A multiwallked carbon nanotube (MWCNT) disk-solid phase extracction (SPE )system coupled to FAAS was established for the separation, preconcentration, and determination of iron, manganese, nickel, and zinc in food and water samples. The Congo Red (CR) chelate worked well for these metal ions as complexing reagent. The method exhibited good precision, accuracy, sensitivity, and allows the determination of these elements in real and certified samples at $\mu \mathrm{g} / \mathrm{kg}$ levels. The multi-walled carbon nanotube ( $40 \mathrm{mg}$ ) can be reused until the end of a study without any loss in its adsorption properties. The procedure shows high tolerance to interference from matrix ions. The determination of elements in food and water samples using the proposed method is novel, rapid, easy, economical, and green.

\section{ACKNOWLEDGMENT}

The authors thank Erkan Yilmaz for his help with the experiments.

Influences of Matrix Ions

\begin{tabular}{|c|c|c|c|c|c|c|}
\hline \multirow{2}{*}{ Ion } & \multirow{2}{*}{$\begin{array}{l}\text { Conc.. } \\
(\mathrm{mg} / \mathrm{L})\end{array}$} & \multirow[b]{2}{*}{ Added as: } & \multicolumn{4}{|c|}{ Recovery (\%) } \\
\hline & & & $\mathrm{Fe}(\mathrm{III})$ & $\mathrm{Mn}(\mathrm{II})$ & $\mathrm{Ni}(\mathrm{II})$ & $\mathrm{Zn}(\mathrm{II})$ \\
\hline $\mathrm{Na}^{+}$ & 5000 & $\mathrm{NaCl}$ & 98 & 97 & 99 & 98 \\
\hline $\mathrm{K}^{+}$ & 2500 & $\mathrm{KCl}$ & 99 & 100 & 97 & 100 \\
\hline $\mathrm{Mg}^{2+}$ & 2500 & $\mathrm{Mg}\left(\mathrm{NO}_{3}\right)_{2}$ & 96 & 98 & 98 & 99 \\
\hline $\mathrm{Ca}^{2+}$ & 2500 & $\mathrm{CaCl}_{2}$ & 88 & 91 & 89 & 90 \\
\hline $\mathrm{Ca}^{2+}$ & 1000 & $\mathrm{CaCl}_{2}$ & 97 & 96 & 96 & 97 \\
\hline $\mathrm{Cu}^{2+}$ & 10 & $\mathrm{Cu}\left(\mathrm{NO}_{3}\right)_{2} \cdot 3 \mathrm{H}_{2} \mathrm{O}$ & 95 & 97 & 96 & 95 \\
\hline $\mathrm{Cd}^{2+}$ & 10 & $\mathrm{Cd}\left(\mathrm{NO}_{3}\right)_{2} \cdot 4 \mathrm{H}_{2} \mathrm{O}$ & 97 & 96 & 95 & 100 \\
\hline $\mathrm{Pb}^{2+}$ & 10 & $\mathrm{~Pb}\left(\mathrm{NO}_{3}\right)_{2}$ & 96 & 100 & 100 & 98 \\
\hline $\mathrm{Co}^{2+}$ & 10 & $\mathrm{Co}\left(\mathrm{NO}_{3}\right)_{2} \cdot 6 \mathrm{H}_{2} \mathrm{O}$ & 99 & 98 & 97 & 99 \\
\hline $\mathrm{Fe}^{3+}$ & 10 & $\mathrm{Fe}\left(\mathrm{NO}_{3}\right)_{3} \cdot 9 \mathrm{H}_{2} \mathrm{O}$ & - & 93 & 92 & 97 \\
\hline $\mathrm{Mn}^{2+}$ & 10 & $\mathrm{MnSO}_{4} \cdot \mathrm{H}_{2} \mathrm{O}$ & 95 & - & 90 & 98 \\
\hline $\mathrm{Ni}^{2+}$ & 10 & $\mathrm{Ni}\left(\mathrm{NO}_{3}\right)_{2} \cdot 6 \mathrm{H}_{2} \mathrm{O}$ & 94 & 91 & - & 96 \\
\hline $\mathrm{Zn}^{2+}$ & 10 & $\mathrm{Zn}\left(\mathrm{NO}_{3}\right)_{2}$ & 100 & 97 & 96 & - \\
\hline $\mathrm{Cl}^{-}$ & 5000 & $\mathrm{NH}_{4} \mathrm{Cl}$ & 98 & 95 & 97 & 94 \\
\hline $\mathrm{CO}_{3}{ }^{2-}$ & 2500 & $\mathrm{Na}_{2} \mathrm{CO}_{3}$ & 100 & 99 & 99 & 100 \\
\hline $\mathrm{SO}_{4}^{2-}$ & 2500 & $\mathrm{Na}_{2} \mathrm{SO}_{4}$ & 98 & 97 & 98 & 99 \\
\hline
\end{tabular}

Received November 23, 2012.

TABLE IV

The Detection Lmit for the Analyte Elements by the Proposed Method $\left(\mathrm{V}_{\text {sample }}=200 \mathrm{~mL}\right.$ and $V_{\text {final }}=10 \mathrm{~mL}$ )

\begin{tabular}{lc}
\hline Analyte & $\begin{array}{c}\text { Limit of } \\
\text { Detection }(\mathrm{ng} / \mathrm{mL})\end{array}$ \\
\hline $\mathrm{Fe}(\mathrm{III})$ & 4.2 \\
$\mathrm{Mn}(\mathrm{II})$ & 1.2 \\
$\mathrm{Ni}(\mathrm{II})$ & 2.1 \\
$\mathrm{Zn}$ (II) & 1.8 \\
\hline
\end{tabular}


TABLE V

Test of Addition/Recovery for Analyte Elements for Water Samples

$(\mathrm{N}=3)\left(\mathrm{V}_{\text {sample }}=200 \mathrm{~mL}\right.$ and $\left.\mathrm{V}_{\text {final }}=10 \mathrm{~mL}\right)$

\begin{tabular}{|c|c|c|c|c|c|c|c|c|}
\hline & \multicolumn{2}{|c|}{ Mineral Water 1} & \multicolumn{2}{|c|}{ Mineral Water 2} & \multicolumn{2}{|c|}{ Seawater from Black Sea } & \multicolumn{2}{|c|}{ Tap Water from Beytepe } \\
\hline & $\begin{array}{l}\text { Added } \\
(\mu \mathrm{g})\end{array}$ & $\begin{array}{l}\text { Found } \\
(\mu \mathrm{g})\end{array}$ & $\begin{array}{c}\text { Added } \\
(\mu \mathrm{g})\end{array}$ & $\begin{array}{c}\text { Found } \\
(\mu \mathrm{g})\end{array}$ & $\begin{array}{c}\text { Added } \\
(\mu \mathrm{g})\end{array}$ & $\begin{array}{l}\text { Found } \\
(\mu \mathrm{g})\end{array}$ & $\begin{array}{c}\text { Added } \\
(\mu \mathrm{g})\end{array}$ & $\begin{array}{c}\text { Found } \\
(\mu \mathrm{g})\end{array}$ \\
\hline \multirow[t]{3}{*}{$\mathrm{Fe}(\mathrm{IIII})$} & 0 & $55.0 \pm 1.3$ & 0 & $43.0 \pm 1.7$ & 0 & $35.9 \pm 1.6$ & 0 & $67.4 \pm 1.8$ \\
\hline & 20 & $73.0 \pm 2.0$ & 10 & $52.0 \pm 2.1$ & 10 & $44.0 \pm 1.2$ & 20 & $85.0 \pm 1.3$ \\
\hline & 40 & $96.0 \pm 2.4$ & 20 & $61.0 \pm 1.5$ & 20 & $55.5 \pm 1.9$ & 40 & $108.7 \pm 2.4$ \\
\hline \multirow[t]{3}{*}{$\mathrm{Mn}(\mathrm{II})$} & 0 & $2.9 \pm 0.4$ & 0 & $1.9 \pm 0.6$ & 0 & $15.9 \pm 1.3$ & 0 & $10.5 \pm 0.8$ \\
\hline & 5 & $7.7 \pm 0.5$ & 5 & $6.5 \pm 0.3$ & 20 & $36.2 \pm 2.1$ & 5 & $15.6 \pm 1.4$ \\
\hline & 10 & $13.1 \pm 0.8$ & 10 & $10.9 \pm 0.6$ & 40 & $54.9 \pm 2.6$ & 10 & $21.2 \pm 1.7$ \\
\hline \multirow[t]{3}{*}{$\mathrm{Ni}(\mathrm{II})$} & 0 & BDL & 0 & BDL & 0 & $5.4 \pm 0.5$ & 0 & BDL \\
\hline & 10 & $11.1 \pm 0.7$ & 10 & $10.7 \pm 0.8$ & 10 & $15.1 \pm 1.0$ & 5 & $5.2 \pm 0.4$ \\
\hline & 20 & $22.0 \pm 1.3$ & 20 & $21.5 \pm 1.0$ & 20 & $26.0 \pm 1.9$ & 10 & $10.7 \pm 0.8$ \\
\hline \multirow[t]{3}{*}{$\mathrm{Zn}(\mathrm{II})$} & 0 & $3.4 \pm 0.5$ & 0 & $24.0 \pm 1.3$ & 0 & $4.9 \pm 0.6$ & 0 & $267.0 \pm 2.5$ \\
\hline & 5 & $8.7 \pm 0.8$ & 10 & $36.0 \pm 1.1$ & 5 & $10.1 \pm 0.5$ & 25 & $289.6 \pm 2.3$ \\
\hline & 10 & $13.9 \pm 0.9$ & 20 & $43.0 \pm 0.7$ & 10 & $14.2 \pm 1.3$ & 50 & $313.5 \pm 2.7$ \\
\hline
\end{tabular}

${ }^{\mathrm{a}}$ Mean \pm standard deviations. $\quad$ BDL: Below the detection limit.

TABLE VI

Levels of Analyte Ions in CRMs After Application of Proposed SPE Method (N = 2)

\begin{tabular}{lcllc}
\hline Sample & Ion & Certified Value & Found Value & Recovery (\%) \\
\hline NCS ZC 73012 & Fe(III) & $98 \pm 10 \mu \mathrm{g} / \mathrm{g}$ & $100 \pm 5 \mu \mathrm{g} / \mathrm{g}$ & 102 \\
(Cabbage) & $\mathrm{Mn}(\mathrm{II})$ & $18.7 \pm 0.8 \mu \mathrm{g} / \mathrm{g}$ & $17.6 \pm 1 \mu \mathrm{g} / \mathrm{g}$ & 94 \\
& $\mathrm{Ni}(\mathrm{III})$ & $0.93 \pm 0.10 \mu \mathrm{g} / \mathrm{g}$ & $0.89 \pm 0.15 \mu \mathrm{g} / \mathrm{g}$ & 96 \\
& $\mathrm{Zn}$ (II) & $26 \pm 2 \mu \mathrm{g} / \mathrm{g}$ & $25.2 \pm 0.9 \mu \mathrm{g} / \mathrm{g}$ & 97 \\
\hline SPS SW1 & $\mathrm{Fe}(\mathrm{III})$ & $20 \mathrm{ng} / \mathrm{mL}$ & $19.8 \pm 0.3 \mathrm{ng} / \mathrm{mL}$ & 99 \\
(Surface Water) & $\mathrm{Mn}(\mathrm{II})$ & $10 \mathrm{ng} / \mathrm{mL}$ & $10.3 \pm 0.5 \mathrm{ng} / \mathrm{mL}$ & 103 \\
& $\mathrm{Ni}(\mathrm{III})$ & $10 \mathrm{ng} / \mathrm{mL}$ & $9.8 \pm 0.4 \mathrm{ng} / \mathrm{mL}$ & 98 \\
& $\mathrm{Zn}$ (II) & $20 \mathrm{ng} / \mathrm{mL}$ & $19.5 \pm 0.7 \mathrm{ng} / \mathrm{mL}$ & 98 \\
\hline
\end{tabular}

TABLE VII

Levels of Analytes in Various Food Samples $(\mathrm{N}=2)$ $\left(V_{\text {sample }}=200 \mathrm{~mL}\right.$ and $\left.V_{\text {final }}=10 \mathrm{~mL}\right)$

\begin{tabular}{lclll}
\hline & & \multicolumn{2}{c}{ Concentration $(\mu \mathrm{g} / \mathrm{g})$} & \multicolumn{1}{c}{$\mathrm{Zn}$} \\
\hline Sample & $\mathrm{Fe}$ & $\mathrm{Mn}$ & $\mathrm{Ni}$ & $9.5 \pm 0.9$ \\
Tomato & $53.0 \pm 1.1$ & $6.6 \pm 0.5$ & $\mathrm{BDL}$ & $53.1 \pm 1.5$ \\
Zucchini & $86.0 \pm 1.2$ & $18.9 \pm 1.1$ & $3.6 \pm 0.2$ & $68.8 \pm 0.9$ \\
Lettuce & $79.9 \pm 1.0$ & $47.7 \pm 1.6$ & $1.4 \pm 0.1$ & $4.7 \pm 0.7$ \\
Bread & $60.0 \pm 0.9$ & $5.9 \pm 0.4$ & $\mathrm{BDL}$ & $47.2 \pm 0.6$ \\
Almond & $87.2 \pm 0.5$ & $23.6 \pm 1.9$ & $0.78 \pm 0.01$ & 4
\end{tabular}

BDL: below the detection limit.

\section{REFERENCES}

1. F. Fu and Q. Wang, J. Environ. Manag. 92, 407 (2011)

2. I. Durukan, Ç.A. Sahin, N. Satiroglu, and S. Bektas, Microchem. J. 99, 159 (2011).

3. O.I. Ilhak, P. Karatepe, and M. Ozcelik, F.U. Sag. Bil. Vet. Derg. 26, 99 (2012).

4. A.S. Souza, G.C. Brandão, W.N.L. dos Santos, V.A. Lemos, E.M.

Ganzarolli, R.E. Bruns, and S.L.C. Ferreira, J. Hazard. Mater. 141, 540 (2007).

5. N. Şatıroğlu and İ. Tokgöz, Int. J. Environ. An. Ch. 90, 560 (2010).

6. M. Soylak and N.D. Erdogan, J. Hazard. Mater. 137, 1035 (2006).

7. B.B. Kefi, L.L. El Atrache, H. Kochkar, and A. Ghorbel, J. Environ. Sci. 23, 860 (2011).

8. Y.-q. Cai, Y.-e. Cai, S.-f. Mou, and Y.q. Lu, J. Chromatogr. A. 1081, 245 (2005).

9. K. Yang, X. Wang, L. Zhu, and B. Xing, Environ. Sci. Technol. 40, 5804 (2006) 
10. W.-D. Wang, Y.-M. Huang, W.-Q. Shu, and J. Cao, J. Chromatogr. A. 1173, 27 (2007).

11. S.G. Ozcan, N. Satiroglu, and M. Soylak, Food Chem. Toxicol. 48, 2401 (2010).

12. C.-Y. Kuo, and H.-Y. Lin, Desalination 249, 792 (2009).

13. K. Pillay, E.M. Cukrowska, and N.J. Coville, J. Hazard. Mater. 166, 1067 (2009).

14. M. Soylak and Y.E. Unsal, Food Chem. Toxicol. 48, 1511 (2010).

15. Y. Li, F. Liu, B. Xia, Q. Du, P. Zhang, D. Wang, Z. Wang, and Y. Xia, J. Hazard. Mater. 177, 876 (2010).

16. M.I. Kandah and J.-L. Meunier, J. Hazard. Mater. 146, 283 (2007).

17. A. Ikem, A. Nwankwoala, S. Odueyungbo, K. Nyavor, and N. Egiebor, Food Chem. 77, 439 (2002)

18. Z. Bouariche, K. Belhamel, M. Benamor, C. Meziti, K. Younsi, and I. Hassaini, J. Coordin. Chem. 63, 1763 (2010).

19. E. Melek, M. Tuzen, and M. Soylak, Anal. Chim. Acta. 578, 213 (2006).

20. Y.-M. Ren, X.-Z. Wei, and J. Ma, Mater. Sci. Technol. 17, 680 (2009).

21. I. Narin, and M. Soylak, Anal. Chim. Acta. 493, 205 (2003).

22. M. Konecna, J, Komarek, and L.Trnkova, Spectrochim. Acta B. 63, 700 (2008)

23. L. Elci, M. Soylak, A. Uzun, E. Buyukpatir,and M. Dogan, Fresenius J. Anal. Chem. 368, 358 (2000).

24. T.Q. Shi, P. Liang, J. Li, Z.C. Jiang, and B. Hu, Chinese J. Anal. Chem. 32, 1495 (2004).

25. M. Soylak, U. Divrikli, and M. Dogan, J. Trace Microprobe Tech. 15, 197 (1997).

26. J.L. Wang, G.H. Liu, X.R. and Zhang, Chinese J. Anal. Chem. 32, 1006 (2004).

27. M. Soylak and I. Murat, Food Anal. Method. 5, 1003 (2012).

28. P. Liang, T.Q. Shi, and J. Li, Int. J. Environ.l Anal. Chem. 84, 315 (2004).
29. M. Soylak and Y. Akkaya, J. Trace Microprobe Tech. 21, 455 (2003).

30. M. Tuzen, M. Soylak, and L. Elci, Anal. Chim. Acta. 548, 101 (2005).

31. A. Islam, M.A. Laskar, and A. Ahmad, J. Chem. Eng., 55, 5553 (2010).

32. M. Soylak, and L. Elci, J. Trace Microprobe Techn., 18, 397 (2000)

33. L.H.Yang, B.Hu, Z.C.Jiang, and H.L. Pan, Microchim. Acta, 144, 227 (2004).

34. S. Saracoglu, M. Soylak, M. Dogan, and L. Elci, Anal. Sci., 19, 259 (2003).

35. P. Liang, L.H.Yang, B. Hu, and Z.C. Jiang, Anal. Sci., 19, 1167 (2003).

36. S. Saracoglu, M. Soylak, and L. Elci, Trace Elemen. Electroly., 18, 129 (2001).

37. P. Liang, Y.C. Qin, B. Hu, T.Y. Peng, and Z.C. Jiang, Anal. Chim. Acta, 440, 207 (2001).

38. M. Soylak, and M. Tuzen, J. Hazard. Mater., 152, 656 (2008).

39. M. Soylak, and Y.E. Unsal, Environ. Monit. Assess., 181, 577 (2011). 